\title{
Drilling through the largest magma chamber on Earth: Bushveld Igneous Complex Drilling Project (BICDP)
}

\author{
R. B. Trumbull ${ }^{1}$, L. D. Ashwal ${ }^{2}$, S. J. Webb ${ }^{2}$, and I. V. Veksler ${ }^{1}$ \\ ${ }^{1}$ GFZ German Research Centre for Geosciences, Telegrafenberg, 14473 Potsdam, Germany \\ ${ }^{2}$ School of Geosciences, University of the Witwatersrand, Johannesburg, South Africa
}

Correspondence to: R. B. Trumbull (robert.trumbull@gfz-potsdam.de)

Received: 1 December 2014 - Revised: 31 March 2015 - Accepted: 13 April 2015 - Published: 29 May 2015

\begin{abstract}
A scientific drilling project in the Bushveld Igneous Complex in South Africa has been proposed to contribute to the following scientific topics of the International Continental Drilling Program (ICDP): large igneous provinces and mantle plumes, natural resources, volcanic systems and thermal regimes, and deep life. An interdisciplinary team of researchers from eight countries met in Johannesburg to exchange ideas about the scientific objectives and a drilling strategy to achieve them. The workshop identified drilling targets in each of the three main lobes of the Bushveld Complex, which will integrate existing drill cores with new boreholes to establish permanently curated and accessible reference profiles of the Bushveld Complex. Coordinated studies of this material will address fundamental questions related to the origin and evolution of parental Bushveld magma(s), the magma chamber processes that caused layering and ore formation, and the role of crust vs. mantle in the genesis of Bushveld granites and felsic volcanic units. Other objectives are to study geophysical and geodynamic aspects of the Bushveld intrusion, including crustal stresses and thermal gradient, and to determine the nature of deep groundwater systems and the biology of subsurface microbial communities.
\end{abstract}

1

\section{Introduction}

With on the order of 1 million $\mathrm{km}^{3}$ of igneous rocks, the Bushveld Igneous Complex is by far the world's largest igneous intrusion, preserving a unique record of magma chamber processes on a truly grand scale. In fact, Bushveld by itself is a large igneous province (LIP) according to criteria of Bryan and Ernst (2008): $>10^{5} \mathrm{~km}^{3}$ of magma, mostly mafic in composition but commonly also felsic; and a short (ca. 1 million year) duration of magmatism. The enormous size and rapid emplacement of the Bushveld intrusion poses first-order questions about how vast amounts of magma are generated from the mantle and emplaced in the crust, and what consequences these processes have, both geodynamically and in terms of the palaeo-environment.

The Bushveld Complex is well layered and bimodal in composition, with subequal proportions of mafic (layered ultramafic and mafic cumulate rocks) and felsic units (roofzone granites and felsic volcanic rocks). This diversity of magma compositions, and the stratigraphic framework pro- vided by its layering, present a rich opportunity to study, in detail, the effects of magma evolution and mixing of melts with diverse mantle and crustal sources. The complex also contains fabulous mineral wealth, with world-class deposits of strategic and precious metals that are vital for both the South African and global economies. Most important of these are the platinum-group metals for which Bushveld alone contains on the order of $70 \%$ of known world reserves, but there are also very important other commodities including $\mathrm{Cr}$ and $\mathrm{V}$. All of these ores are orthomagmatic; that is, they are directly related to igneous processes within the intrusion, so their formation cannot be understood without knowing the inner workings of the magma chamber and vice versa. It should be noted that a large part of current understanding on layered intrusions is based on decades of research of the Skaergaard intrusion in Greenland, which is tiny compared to Bushveld (Fig. 1) and appears to represent just one intrusive episode followed by closed-system crystallization. Some features of layering in the Bushveld Complex are similar to Skaergaard, but Bushveld shows evidence for multiple intru- 


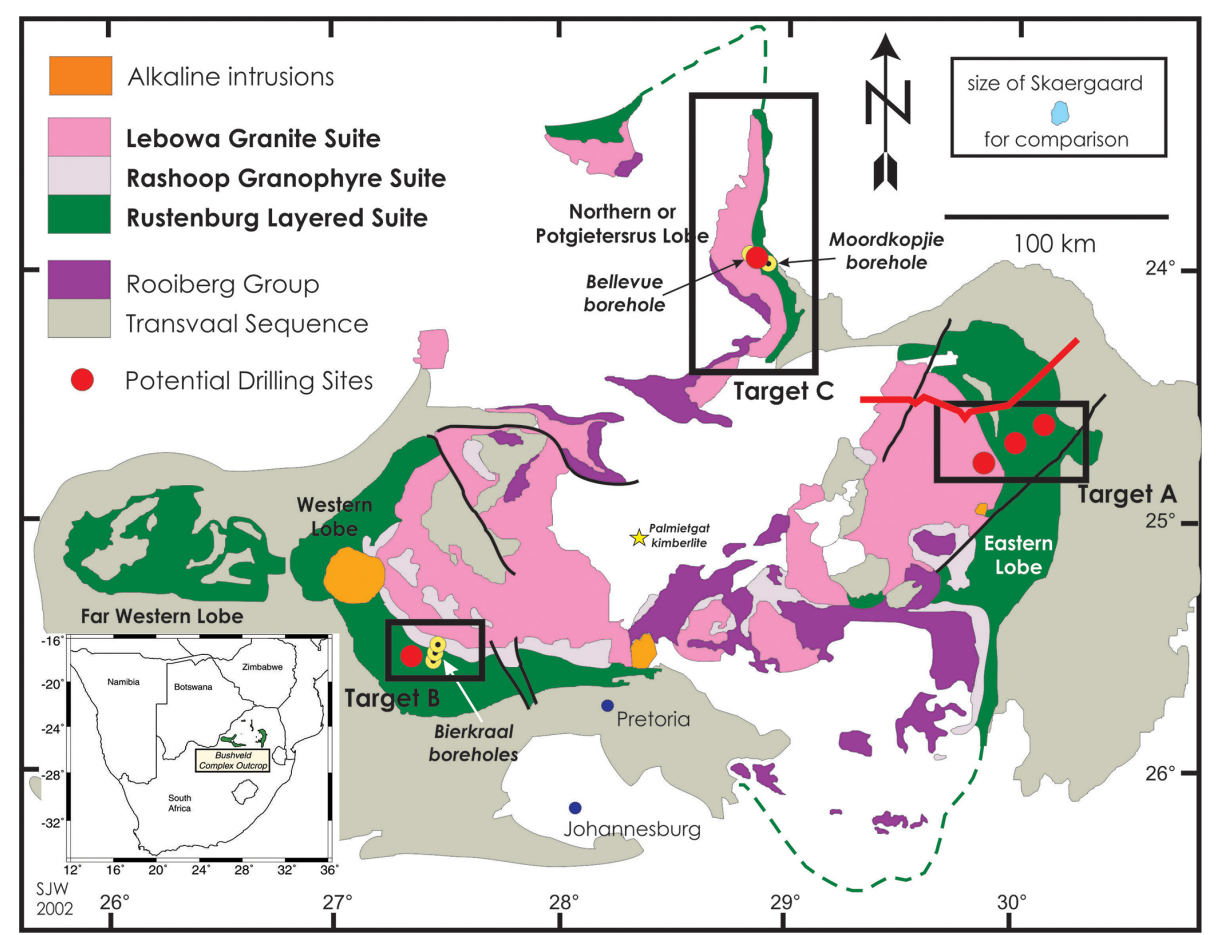

Figure 1. A simplified map of the Bushveld Complex with location of existing boreholes (yellow) and the potential ICDP sites in the western, northern and eastern lobes (red dots in boxes). The inset in upper right shows the size of the iconic Skaergaard layered intrusion for comparison. The thick red line above target $\mathrm{A}$ is a reflection seismic line of the Council for Geoscience. The Palmietgat kimberlite in the centre of the complex (star) contains Bushveld xenoliths, confirming geophysical evidence for a continuity of $\mathrm{E}$ and $\mathrm{W}$ lobes (see text).

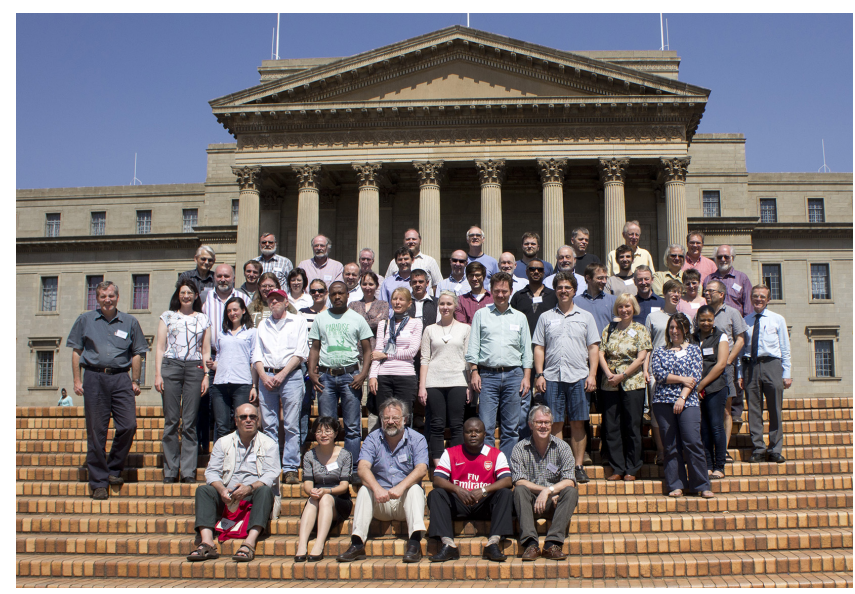

Figure 2. Bushveld workshop participants pose in front of the Great Hall at Wits University.

sive pulses and for chemical interaction with the host rocks, which adds layers of complexity to the Skaergaard model.

The motivation for an International Continental Drilling Program (ICDP) project in the Bushveld Complex is to focus and coordinate efforts of the international community towards solving outstanding scientific questions that can best be studied in this world-class location (see below for a list of the main goals). An essential and central part of this project will be to establish permanently curated stratigraphic reference profiles of the Bushveld Complex accessible for future research. But Bushveld is not just a window into Earth processes at depth and in the past, it is also a major socio-economic focus in South Africa. Therefore, issues of land use, hydrogeology, mine safety and public awareness of "geo-issues" are equally part of the equation. And a very important benefit of the ICDP project will be to provide international exposure, research and training opportunities to students and young researchers from all participating countries and from South Africa in particular. Finally, the economic importance of the Bushveld Complex means that the mining and mineral support industries are very active. This is an advantage for the ICDP project because of the local drilling expertise, and also because of industry involvement, with inkind contributions of data and core materials to the archive, and possibly also with help to offset the drilling costs.

Putting all of these aspects into the framework of an ICDP project proposal was the goal of an international workshop that took place in Johannesburg from 7 to 10 September, 2014, under the sponsorship of ICDP and hosted by the University of the Witwatersrand's School of Geosciences (Fig. 2). The workshop was attended by 55 delegates representing South Africa, Germany, UK, Denmark, Austria, Canada, Australia and the People's Republic of China. In ad- 
dition to researchers from academia, the workshop attracted participation from South Africa's Council for Geoscience, the Water Research Commission and the mining sector. Six of the participants were postgraduate students engaged in Bushveld-related research.

Because of the importance of debate and discussion, formal presentations were limited to just a few keynote talks giving overviews of the three main discipline groups: igneous petrology and metallogenesis, geophysics and geodynamics, and hydrology and microbiology. The main part of the workshop was devoted to the following tasks:

- formulating the key scientific questions and the role of drilling in answering them;

- exploring synergies among the discipline groups and stakeholders, and any special conditions of drilling needed to accommodate them;

- choosing the best drill site or combination of drill sites to achieve maximum scientific benefits within a realistic scope of logistics and costs;

- establishing working groups and a steering committee to carry the momentum forward to a full drilling proposal.

\section{Scientific background and controversies}

The Bushveld Igneous Complex includes a mafic/ultramafic layered sequence called the Rustenburg Layered Suite (RLS), which contains the main ore horizons, and two suites of felsic intrusive units above: the Rashoop Granophyres and the Lebowa Granite. The youngest member of the complex is volcanic: the Rooiberg felsic lavas. Controversies exist about the genetic relationship between the felsic and mafic magmas (VanTongeren et al., 2010), as well as about the links of intrusive vs. extrusive magmatic units (Buchanan et al., 2004; Mathez et al., 2013). For example, Walraven (1997) determined an age for the Rooiberg volcanics at $2061 \pm 2 \mathrm{Ma}$ (million years ago), which is statistically indistinguishable from U-Pb zircon ages of 2055-2060 Ma obtained from various parts of the Rustenburg Layered Series (Buick et al., 2001; Scoates and Friedman, 2008). Very recent highprecision dating by Zeh et al. (2014) limits the time of emplacement for the entire $8 \mathrm{~km}$ thick layered series to less than 1.6 million years, which places important constraints on, and offers new fuel for debates about, the processes of magma generation and evolution, crystallization and layering of the magma chamber, the formation of ore deposits and the postmagmatic effects related to cooling and wall-rock interaction.

The exposed part of the Bushveld Complex is divided into western, northern and eastern lobes (Fig. 1). The arcuate east and west lobes appear to be connected at depth based on gravity models and seismic tomography (Webb et al., 2004;
Kgaswane et al., 2012), and this was supported by discovery of layered-series xenoliths brought up in the central Palmietgat kimberlite (Webb et al., 2011; see Fig. 1). Most of the currently mined ore deposits are located in the western and eastern lobes, but the northern lobe also contains important platinum-group element (PGE) deposits (e.g. Platreef) and there is active exploration ongoing. Finally, there are mostly hidden or eroded remnants of the RLS in the far west and in the south (dashed lines on Fig. 1). These parts of the intrusion are surprisingly similar given the great distances between them; however, there are lateral changes in thickness and continuity of some units that have implications for economic geology and have sparked ongoing debates on the sequence of magma-chamber filling and the importance of sedimentary processes like gravity-driven slumping, scouring and crystal slurry transport (e.g. Maier et al., 2013).

\section{The need for drilling: goals and benefits of an ICDP project}

The Bushveld Complex had been studied geologically even before the discovery of platinum there in 1924, and it continues to attract international research (e.g. 13 ISI publications in 2014). However, partly because of its sheer size and complexity, but also for lack of research coordination and access to drill-core samples, which are mostly held by industry and pertain to only the narrow mineralized intervals, the work has been piecemeal. Most of the $8 \mathrm{~km}$ thick layered sequence of the Bushveld Complex is below the surface. Spotty access by mining operations or fortuitous outcrop reveals only parts of the sequence in detail, and without vertical continuity. Understanding how the Bushveld magmas formed, accumulated and crystallized into layers requires studying a continuous vertical sequence including the roof and floor zones. This cannot be achieved from existing drill cores. Furthermore, some of the interesting scientific topics require techniques or conditions such as oriented core, or fluid and biological sampling, which can only be provided by dedicated new drill holes.

The workshop identified the following sets of scientific questions that ICDP should address:

1. Melt origin, melt evolution and magma chamber processes: How many separate melts were involved in filling the Bushveld magma chamber(s) and over what time interval? From where were these melts derived; how much did they mix and how much left the system? How quickly was the complex assembled and how fast did it cool down?

2. Crust-mantle interactions and origin of the Bushveld granitoids: How large is the proportion of mantle vs. crustal material in the mafic and felsic magmas? Are the two magma series related to each other and, if so, how? 


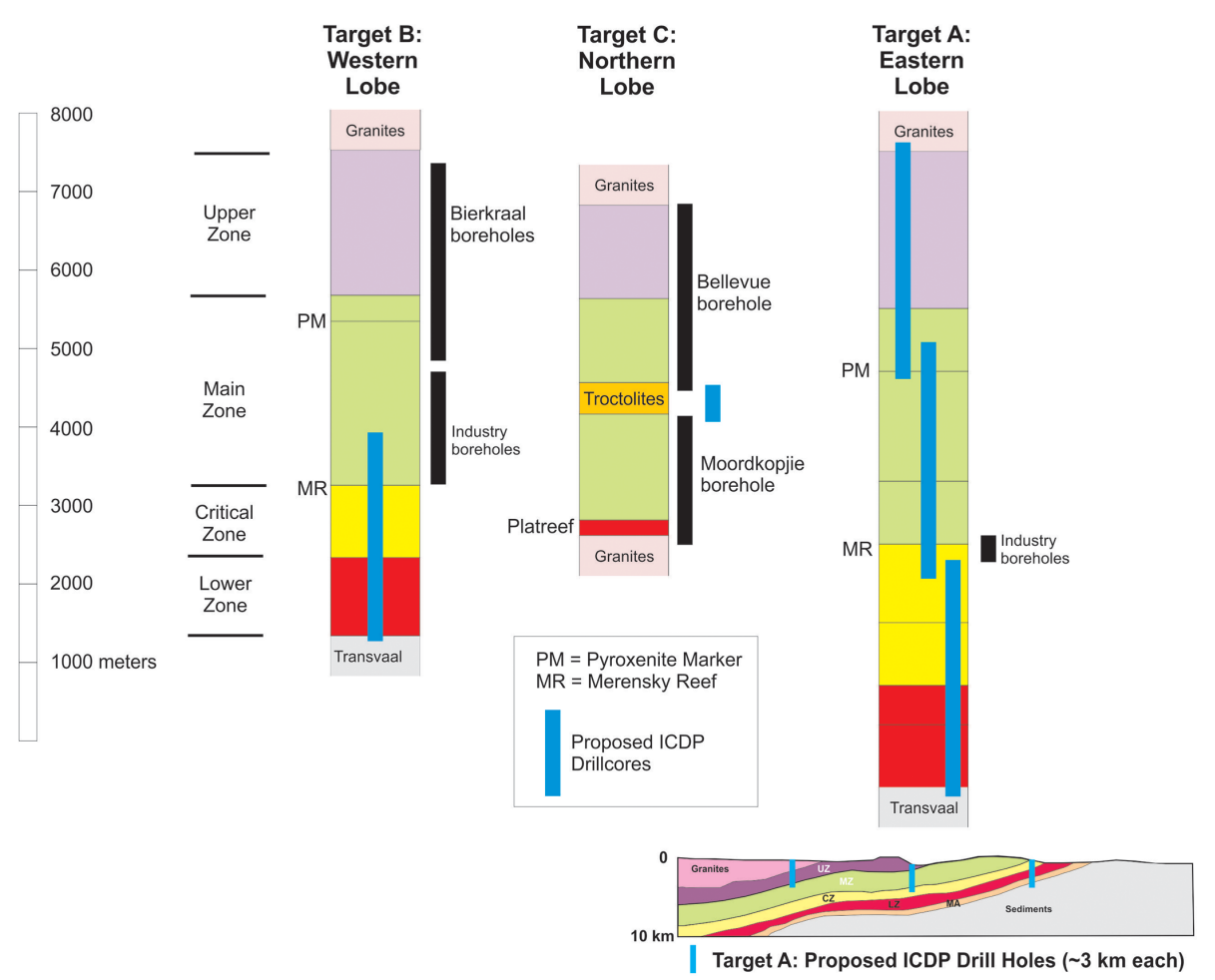

Figure 3. Schematic stratigraphic sections of the Bushveld lobes illustrate ICDP targets A, B and C. The cross section of the eastern lobe (right) explains the staggered-hole concept for target A (see text).

3. Origin of ore deposits: How important were vertical transport processes in the magma through crystal settling and sinking of sulfide melts? What was the role of melt mixing or unmixing in ore formation? How important was lateral transport and reworking of ore zones by hydrothermal fluids?

4. Geophysical properties, geodynamic processes: What isostatic effect did emplacement of the Bushveld magmas have, what are the implications for elastic thickness of the lithosphere? How many magnetic reversals are recorded in the Bushveld mafic section? What is the present state of stress and heat flow in the crust, and their variations with depth?

5. Hydrogeology and the deep biosphere: How is the quantity and quality of deep groundwater in the Bushveld area distributed? What is the effect of mining on these distributions and on hydraulic conductivity? Is there a geothermal potential? What is the nature and productivity of subsurface biomes, what are their energy sources and what role does water-rock interaction play thereby? How old are the deep microbe lineages, and to what extent do near-surface and deep communities interact?

\section{Workshop recommendation and follow-up}

Consensus was reached early on that the central role of the ICDP project should be to establish internationally available reference sections through the Bushveld Complex on which coordinated research can be focused. There must be permanent curation of the drill cores following ICDP best-practice guidelines, and an ideal host institution for this archive would be the South African Council for Geoscience.

The issue of site selection is a difficult one because of the size of Bushveld and its geographic division into three widely separated lobes, each of which has pros and cons for location of a major drilling project. One of the important site considerations was coverage of part of the stratigraphy from existing cores, and/or availability of deep geophysics and other information to guide drilling. Champions for each of the three lobes presented their cases and there was much discussion. A common concern was that any one "reference section" would necessarily neglect lateral variations, which could be critically important for many of the scientific questions. The recommendation therefore was for a combination of targets that would integrate existing cores and allow constructing profiles for all three lobes at reasonable cost/benefit.

The main effort and expense will be invested in the eastern lobe (Target A, Fig. 1), where no deep holes currently exist, and where drilling can be sited to take advantage of the westward dip of the units. For this target, three holes of 
$3000 \mathrm{~m}$ each, spaced along an E-W traverse across the tilted section, would cover the full $9000 \mathrm{~m}$ profile (see Fig. 3). In the western lobe (Target B), existing drill cores (Bierkraal and industry holes) cover the upper section from the roof to mid-intrusion (see Tegner et al., 2006), and it is proposed to continue this downward a further $2500 \mathrm{~m}$ into the floor (Fig. 3). For the northern lobe, too (Target C), a full reference profile can be achieved by adding about $500 \mathrm{~m}$ to two existing cores (Bellevue, Moordkopjie), which have been described by Ashwal et al. (2005), Roelofse and Ashwal (2012) and Tanner et al. (2014).

The workshop recommendation, therefore, calls for a combined drilling project to obtain about $12000 \mathrm{~m}$ of core, much of it oriented to allow for palaeomagnetic studies. While this is a very ambitious proposal implying substantial investments, we are convinced that it is justified by the benefits of obtaining not one but three archived reference profiles through the world's largest layered intrusion and platinum orebody, which will permit research on both the vertical and lateral variations.

The final achievement of the Bushveld workshop was to appoint a steering committee representing the main scientific groups and all participating countries, as well as several task groups to solve outstanding issues needed in preparation of a full drilling proposal. These include three drill site groups that will collect existing information needed to specify the exact drilling targets, a liaison group to inform and enlist support from industry, community and regulatory agencies in South Africa, and a group to draft plans for outreach and capacity building modules.

Acknowledgements. First thanks goes to all participants for their input to the workshop and to many of them who agreed to take on tasks going forward. The Bushveld workshop was funded by a grant from the ICDP, which is greatly appreciated. The School of Geosciences of the University of the Witwatersrand and its head Roger Gibson were excellent hosts. Special thanks are due to Ulrich Harms of the ICDP Operational Support Group for his buoyant enthusiasm, encouragement and good advice. This workshop report benefitted from constructive reviews by Takashi Hoshide and an anonymous referee.

Edited by: T. Morishita

Reviewed by: T. Hoshide and one anonymous referee

\section{References}

Ashwal, L. D., Webb, S. J., and Knoper, M. W.: Physical and mineralogical properties of Bushveld rocks: magnetic susceptibility and mineral chemistry profiles in the $2950 \mathrm{~m}$ Bellevue drillcore, Northern Lobe, S. Afr. J. Geol., 108, 199-232, 2005.

Bryan, S. E. and Ernst, R. E.: Revised definition of large igneous provinces (LIPs), Earth-Sci. Rev., 86, 175-202, 2008.
Buchanan, P. C., Reimold, W. U., Koeberl, C., and Kruger, F. J.: $\mathrm{Rb}-\mathrm{Sr}$ and $\mathrm{Sm}-\mathrm{Nd}$ isotopic compositions of the Rooiberg Group: early Bushveld-related volcanism, Lithos, 29, 373-388, 2004.

Buick, I. S., Maas, R., and Gibson, R.: Precise U-Pb titanite age constraints on the emplacement of the Bushveld Complex, South Africa, J. Geol. Soc. London, 158, 3-6, 2001.

Kgaswane, E. M., Nyblade, A. A., Durrheim, R. J., Julià, J., Dirks, P. H. G. M., and Webb, S. J.: Shear wave velocity structure of the Bushveld Complex, South Africa, Tectonophysics, 554, 83-104, 2012.

Maier, W. D., Barnes, S., and Groves, D. I.: The Bushveld Complex, South Africa: formation of platinum-palladium, chromeand vanadium-rich layers via hydrodynamic sorting of a mobilized cumulate slurry in a large, relatively slowly cooling, subsiding magma chamber, Miner. Deposita, 48, 1-56, 2013.

Mathez, E. A., Van Tongeren, J. A., and Schweitzer, J.: On the relationships between the Bushveld Complex and its felsic roof rocks, part 1: petrogenesis of the Rooiberg and related felsites, Contrib. Mineral. Petr., 166, 435-449, 2013.

Roelofse, F. and Ashwal, L. D.: Lower Main Zone in the northern limb of the Bushveld Complex - A > $1.3 \mathrm{~km}$ thick sequence of intruded and variably contaminated crystal mushes, J. Petrol., 53, 1449-1476, 2012.

Scoates, J. S. and Friedman, R. M.: Precise age of the platiniferous Merensky reef, Bushveld Complex, South Africa, by the U-Pb zircon chemical abrasion ID-TIMS technique, Econ. Geol., 103, 465-471, 2008.

Tanner, D., Mavrogenes, J. A., Arculus, R. J., and Jenner, F. E.: Trace element stratigraphy of the Bellevue core, northern Bushveld: magma injections obscured by diffusive processes, J. Petrol., 55, 859-882, 2014.

Tegner, C., Cawthorn, R. G., and Kruger, F. J.: Cyclicity in the main and upper zones of the Bushveld Complex South Africa: crystallization from a zoned magma sheet, J. Petrol., 47, 2257-2279, 2006.

VanTongeren, J., Mathez, E. A., and Kelemen, P.: A felsic end to Bushveld differentiation, J. Petrol., 51, 1891-1942, 2010.

Walraven, F.: Geochronology of the Rooiberg Group, Transvaal Supergroup, South Africa, Economic Geology Research Unit, Information Circular 316, Johannesburg, University of the Witwatersrand, 1997.

Webb, S. J., Nguuri, T. K., Cawthorn, R. G., and James, D. E.: Gravity modelling of Bushveld Complex connectivity supported by southern African seismic experiment results, S. Afr. J. Geol., 107, 207-218, 2004.

Webb, S. J., Ashwal, L. D., and Cawthorn, R. G.: Continuity between eastern and western Bushveld Complex, confirmed by xenoliths from kimberlites, Contrib. Mineral. Petr., 162, 101107, 2011.

Zeh, A., Ovtcharova, M., Wilson, A., and Schaltegger, U.: The Rustenburg Layered Suite (Bushveld Complex) crystallized in less than 1.6 million years - constraints from CA-ID-TIMS dating, geothermometry and inclusions in zircon, 21st Meeting of the International Mineralogical Association, 1-5 September, 2014, Johannesburg, Abstracts volume: 348, 2014. 